\title{
The Effect of Organizational Culture and Organizational Learning towards the Competitive Strategy and Company Performance (Case Study of East Java SMEs in Indonesia: Food and Beverage Industry)
}

\author{
Hary Sastrya Wanto ${ }^{1}$, Ruswiati Suryasaputra ${ }^{2}$ \\ 1 Universitas Wijaya Kusuma Surabaya, Indonesia \\ 2Universiti Utara Malaysia, Malaysia \\ *ruswiati@uum.edu.my
}

\begin{abstract}
Organizational culture and learning organizations are the major topics of discussion in corporate world. It is well realized that to become learning Organization is to agree a set of attitudes, values and practices that support the process of constant learning within the organization. A learning culture can be developed in an Organization only when the top management and executive is committed and deeply involved. "Learning Culture" should be a Corporate Goal and stated at the highest level of objectives in order that it is cascaded down to the organizations employees and becomes a part of every employee's personal, annual goals. It is necessary to establish the relation between culture, learning climate and strategic performance, in order to provide effective direction to the modern organizations. A study has been initiated to analyze the organization culture and organization learning effects toward the Competitive Strategy and Company Performance From the 615 Small and Medium-sized Enterprises in East Javas population, the sample are 143 from the three biggest cities in East Java Indonesia (Surabaya, Malang and Kediri) as the location of this research. This research conducted to apply the Explanatory Research with the Organizational Culture, Organizational Learning, Competitive Strategy and Company Strategy as a Research Variables. Structural Equation Modeling (SEM) was the appropriate tool to examine and to analyze the data. The results of this research showed that Organization Culture has significant effect towards company Competitive Strategy, Organization Learning has significant effect towards Competitive Strategy, but it did not have significant effect towards Company Performance. Moreover, Competitive Strategy has a significance effect towards Company Performance.
\end{abstract}

\section{Keywords: Organizational Culture, Organizational Learning, Competitive Strategy, Company Performance}

\section{Introduction}

Modern organizations are witnessing drastic changes in its approaches at operational level as well as strategic level. These changes are percolated at the shop floor level and compelled management to go with strategic innovation and learning organization mode. It is rightly pointed out by Drucker (1999) that business and technological changes are threatening organizational sustainability and modern management faces many challenges. Organizations are continually under competitive pressures and forced to re-evaluate come up with new innovations. An innovation can be a new product or service, a new production technology, a new operation procedure or a new management strategy to an enterprise (Damanpour, 1989; Liao, Fei, \& Liu, 2008; Nonaka \& Yamanouchi, 1989; Tushman \& Nadler, 1986; Zaltman, Duncan, \& Holbeck, 1973). Innovations have always been essential for the organizations' long-term survival and growth and currently play even more crucial role in the company's future to follow the rapid pace of markets' evolution (SantosVijande \& Álvarez-González, 2007). Organizational learning is a complex process that refers to the development of new knowledge and has the potential to change behavior (Huber, 1991; Slater \& Narver, 1995). It is a time-honored process that involves changing individual and organizational behavior (Murray \& Donegan, 2003). Firms that have developed a strong learning culture are good at creating, acquiring and transferring knowledge, as well as at modifying behavior to reflect new knowledge and insight (Garvin, 1993; Huber, 1991. Jones (2000) emphasizes the importance of organizational learning for organizational performance. He defines it as "a process through which managers try to increase organizational members" capabilities in order to better understand and manage the organization and its environment' (Jones, 2000). All organizations beyond sectors are affected by the vast changes, which are occurring at national 
international level due to globalization, liberalization and economic crisis impact. In order to fine tune with the global changes the organizations must accept the culture, learning climate and innovation toward better performance. This particular research tried to establish the relationship between organizational cultures and organizational learning towards the competitive strategy and company performance.

According to Chattel (1995), the future firms are the innovative firms, adaptive, and have the abilities to be adaptable with the rapid changing. Moreover, the strategy is compulsory for the firms in order to maintain their existences and achieve their goals and win the competition. Furthermore, the firms should control their industry and generate market in the future; in this case, they can be as the pioneer in that time (Hamel and Prahalad, 1994). Subsequently, the human resource is needed for creating the best vision and mission of the firms so as to generate the strongest organization for facing the globalization. The firms that have the ability in keeping their existences in the globalization era are the firms that can adapt with the environments or to be more flexible, put their stakeholders in the top priority and to be the leader company. Organizations that value systematic approaches to organizational learning thus stress the importance of acquiring all types of information (operational, tactical and strategic) from both internal and external sources. The better a certain firms is at acquiring information the more understanding it can get from it. Varied research input shows that most of Indonesian SMEs have survived during the economy crisis in 1997-1998. The questions rose in this context that how far the human resource in the organization in tune with the culture supports these effective changes? In developing a learning culture employees are expected to play a major role. The ownership and accountability for learning should be on the employees, and the opportunity for learning had been given by the organization. The contract of employment shall be clear about what the company is prepared to offer and what the company expects from the employee towards continuous learning. In this scenario it is necessary to study how far the organizational culture and the learning climate influence the SMEs toward better performance. The study posed several research questions in this context. They are:

- Does the Organizational Culture affect significantly towards Competitive Strategy and Company Performance among Indonesian SMEs, particularly in East Java?

- Does the Organizational Learning affect significantly towards Competitive Strategy and Company Performance among Indonesian SMEs, particularly in East Java?

- Does the Competitive Strategy influence significantly towards Company Performance among Indonesian SMEs, particularly in East Java?

Based on problem statement and the research questions, hence, the research objectives are:

- To analyze the effect of Organizational Culture towards Competitive Strategy and Company Performance.

- To analyze the effect of Organizational Learning towards Competitive strategy and Company Performance.

- To analyze the effect of Competitive Strategy towards Company Performance.

\section{Significance of the Study}

- Significance of the study for practitioners. This study provided the knowledge on how to increase the performance of the company through organizational culture, organizational learning and how to make the competitiveness strategy more success in order to run the business particularly to increase the company performance.

- The Significance of the Study for the Government: The result of this research is expected for helping the government guide to monitor Indonesian SMEs with fully-controlled actions for maintaining the Indonesian SMEs existences and their better performance.

\section{Literature Review}

\section{Theoretical Review}

Organizational Culture, Organizational Learning, Competitive Strategy and Company Performance: Robbins (2001) stated that organizational culture as a shared meaning system formed by its citizens as well as a differentiator with other organizations. Shared meaning system is a set of key characteristics of the 
organization's values - a system of shared meaning held by members that distinguishes the organization from other organizations. This shared meaning system, on closer examination, a set of key characteristics Organizations That the values "). Robbins (2001) gives seven characteristics of organizational culture as follows: (1)innovation and courage to take risks; (2) attention to detail; (3) oriented outcome; (4) oriented in humans; (5) oriented in teams; (6) aggressive and; (7) stability. According to Senge (1990) learning organizations are organizations where people continually develop its capacity to create desired outcomes, with new patterns of thinking, given the freedom and the aspirations of the people in it are constantly learning to learn something together, there are five indicators organizational learning, namely: (i) personal mastery (personal excellence), (2) mental models, (3) shared vision, (4) team learning, and (5) systems thinking, the next Senge (1990) says people who want to compete in business environment must make the organization "Learning Organization" by continuously adapting to the environment. A common strategy according to Porter (1980) includes the Cost Leadership, Product Differentiation, and the Focus has been recognized as a typology of strategies for the organization. Porter's typology has been widely known in the United States since the late 1980's. The extent to which the strategy is implemented in a non-United States markets, and how the strategy was applied in a non-United States culture is the attention of scholars and academics. Performance is the ability to work shown with the result of work, including: (1) the process or manner of performing; (2) a notable action or achievement; (3) the performing of a play or other entertainment - Hawkins in the Oxford Paperback Dictionary, 1979.Company Performance is something produced by a company within a specified period with reference to established standards specified. Corporate performance should be an outcome that can be measured and described the empirical conditions of an enterprise of any size agreed. To determine the performance achieved then the appraisal of performance. According to Law No. 9 of 1995 on Small Enterprises, the restriction of business/small industry is defined as follows: Small industry is the economic activity which is undertaken by individuals or households as well as a firm, and it aims to produce goods or services for commercial trade, which has a net worth of at most Rp. 200 million and has annual sales value of Rp. 1 billion or less.

While there is a consensus that organizational culture is critical in any change initiative, no such consensus exists as to what type of organizational culture best supports business transformation and innovativeness. A lack of empirical investigations into organizational culture on various aspects of innovativeness is still noted. Only a few studies have tackled some aspects of this issue in recent years (e.g. Kandemir \& Hult, 2005; Kusunoki, Nonaka, \& Nagata, 1998; Martins \& Terblanche, 2003; Merx-Chermin \& Nijhof, 2005; Sarros, Cooper, \& Santora, 2008). Findings of Prajogo and McDermott (2005) indicate that an organization can implement different, even opposite culture types, in harmony. This opened up the question of which combination of culture types is most appropriate for innovations. The degree of innovation reflects the extent of new knowledge embedded in an innovation (Dewar \& Dutton, 1986; Ettlie, 1983). Firms with greater innovation capability will achieve a better response from the environment, obtaining more easily the capabilities needed to increase organizational performance and consolidate a sustainable competitive advantage (Calantone et al., 2002; Zaltman et al., 1973). For this reason is necessary to improve the innovative culture of the enterprise so that all its members search new product, services or processes (innovations involve a change, something new - e.g. novel ideas or behaviors).Fang and Wang (2006) defined that the organizational culture and organizational learning has positive and significant impact on competitive strategy. Mavondo and Farrell (2003) stated that the organizational culture significantly influences the strategy and corporate performance. Subsequently, Lopez et al. (2004) mentioned that organizational culture influences performance through organizational learning. According to McGuinness and Morgan (2005), both defined that organizational learning has a positive relationship towards a dynamic strategy in order to improve the organizational performance. Hardley and Mavondo (2000) found out that organizational learning indirectly intercede the impact on company performance. Then, based from Barth (2003),there is a significant relationship between competitive strategies of small firms with corporate performance. Learning is the power of growth, and individual learning is the resource of business growth (Chang and Lee, 2007). Based on the organization metaphor in organization theory, Senge (1990) introduced learning organization theory.

The academic definition of the learning organization covers individual, group, and organizational learning with the effort for organizational and individual learning (Argris and Schon, 1978; Dodgson, 1993; Kim, 1993; 
Popper and Lipshitz, 1995; Shrivastva, 1983; Small and Irvine 2006). It is a type of collective activity to reach the organization's shared vision. Many books (for example, Dixon, 1994; Garratt, 1990; Armstrong and Foley, 2003; Senge, 1990) have been published about the learning organization and many research papers have presented the impact of various variables on learning organizations example, Carroll and Nafukho, 2006; Leitch et al, 1996; Gardiner and Whiting, 1997; Hall, 2001; Örtenbland, 2004; Edmondson and Moingeon 1998).In the current management literature on organizational culture (for example, Deal and Kennedy, 1982; Peters and Waterman, 1982) which includes the work of Schein (1990), culture is widely understood as an instrument to be used by management to shape and control in some way the belief, understandings, and behaviors of individuals, and thus the organization to reach specified goals. Therefore, a number of definitions for any organizational culture have been proposed (for example, Kilman et al, 1985; Uttal, 1983). Many studies have been conducted about the impact of organizational culture on different variables in the organizational setting. In such research, for example, the impact of organizational culture on job satisfaction (Lund, 2003), individual learning (Aksu and Ozdemir, 2005), organizational effectiveness (Denison, 1990; Denison and Mishra, 1995), leadership (Kasper, 2002; Chang and Lee, 2007; Schein, 1992), organizational problem-solving (Bate, 1984), creativity (Koberg and Chusmir, 1987) organizational commitment (Lock and Crawford, 1999), organizational performance (Wilkins and Ouchi, 1983), TQM (Pool, 2000) communication and information (Brown and Starkey, 1994).

\section{Hypotheses}

- Organizational Culture has significant effects towards Competitive Strategy and Company Performance.

- Organizational Learning has significant effects towards Competitive Strategy and Company Performance.

- Competitive Strategy has effect significantly towards Company Performance.

\section{Research Method}

Research Plan: The research was planned by using the variables of Organizational Culture, Organizational Learning, Competitive Strategy and Company Performance. Based from the two previous chapters, which have been explained before namely: (1) problem statement; and (2) literature review, therefore, this research using explanatory patterns.

Population and Sample: Based on data from the Office of Industry and Commerce (2007) in East Java, there are 617 SMEs of processed food products and beverages, to support research is further selected three districts / cities that have a majority of SMEs are Surabaya, Malang and Kediri. Furthermore, based on Isaac et al. (1981) and Sugyono (2004) the number of samples from a population at an error rate of $5 \%$, as outlined in the table below. The number of SMEs in the three cities of Surabaya, Kediri and Malang numbered 165.

Table 1: Sample Research

\begin{tabular}{llll}
\hline No & City Government & Population & Sample \\
\hline 1. & Surabaya & 55 & 48 \\
2. & Kediri & 60 & 51 \\
3. & Malang & 50 & 44 \\
Total & & 165 & 141 \\
\hline
\end{tabular}

Source: Processed Primary Data (2009).

\section{Research Variables}

A) Exogenous constructs (independent variables):

- The organizational culture (indicator: the humanistic, task, support).

- Organizational learning (personal mastery, mental models, shared vision, team learning,) systems thinking.) 
B) Endogenous constructs (dependent variables):

- Competitive Strategy (low cost, differentiation, focus).

- Company Performance (sales growth and profitability)

Data Source: The sources of the data in this research were obtained by using primary data, such as data that related to core issues of objects / subjects of research, and obtained directly from the 143 respondents, namely the SME owners.

Determination Score: Closed-form scales in the questionnaire used in this study using a Likert scale with a standard scale of 1 to 5 . The options on the questionnaire with the Likert scale were strongly disagree (notation 1), disagree (notation 2), neutral (notation 3) agree (notation 4), strongly agree (notation 5).

Data Collection Method: Method of data collection in this research is done by distributing questionnaires, a list of questions that were wanted to be analyzed and researched based on the objectives in this research.

Validity and Reliability Test: Validity test (construct validity) is defined as a measure of how strong a test tool performs the function of its size. If the validity of the obtained higher, then the test will be stronger and show what is actually shown. To determine an indicator / item is valid or not, then it can be seen from the goodness of fit index (GFI), if the value of GFI>0.9 means that the indicators / items declared invalid. Reliability test (construct reliability) was used to test the constancy of measurement results with a questionnaire which was closely related issues of trust (Nazir, 1999). A test is said to have a reliability standard if the test gives an exact test (steady). To determine whether an indicator / item reliable / not, then the views of the construct reliability, for example if the construct reliability value is greater than 0.7 means that the indicators /items otherwise reliable.

Data Analysis Method: In this research, Structural Equation Modeling (SEM) is the appropriate tool in order to measure and analyze the data.

\section{Discussion}

The Effect of Organizational Culture towards Competitive Strategy and Company Performance: The results of SEM analysis of the influence of organizational culture variables (X1) on competitive strategy (Y1) is obtained directly influence the path coefficient p-value 0063 and 0542, in the calculation of this p-value has a value greater than $5 \%$ thus the influence of organizational culture is said to not significantly influence of competitive strategy. The results of the study was not conducted in line with Wang and Fang (2006) and Mavondo and Farrell (2003).Based on the results of this analysis task is the main and most important forming or variables measuring of organizational culture, therefore, SME owners should pay attention to this indicator. The items in this indicator include: formal assignments, informal tasks, the tasks of regular and non-regular duties. We can see from the results of this study, then the owner of the company should pay attention to the tasks given to employees both formal assignments, informal tasks, tasks of regular and non-regular tasks. The results of this study are not in line with research conducted by Fang and Wang (2006) says that organizational culture affects the company's competitive strategy. This difference is possible because the indicators used are different organizational cultures. Indicators of organizational culture that used by Fang and Wang (2006) adopted the opinion of Hofstede (1980), namely power distance, risk avoidance, individualism, and masculinity, as well as the company's competitive strategy for the indicator variables used in this study is different from that used indicators of corporate strategy Fang and Wang (2006) that includes cost, quality, flexibility and reliability company. Other researchers that are not in line with this research is Mavondo and Farrell (2003) shows that there is a significant relationship between organizational culture oriented company with corporate strategy. In conducting research both researchers did not describe the indicators used. Cultural organizations (X1) on the performance of the company (Y2) is obtained directly influence the path coefficients and p-value 0219 and 0015 . In this calculation p-value less than $5 \%$, by thus can be said that the organizational culture 
significantly influence the company performance, then, Given the path coefficient is positive (0219), this means that relations between the two variables is positive, meaning the better the organizational culture, the higher the performance of the company. Research conducted by Siew and Kelvin (2004) looked at the relationship of organizational culture with performance. Indicators of organizational culture that is used is measured in terms of cultural profile or Organization Culture Profile (OCP) (Chatman and Jehn, 1994) has been used as a primary research instrument. The OCP includes innovation, support, team, humanistic, and task, this indicator is virtually identical to that used indicators of organizational culture Bititci et al., (2004) and Bititci et al., (2006). Conclusions put forward by researchers is the culture of the organization have a significant effect on performance. In line with this study Lopez et al., (2004), has conducted research to propose three hypotheses include the influence of organizational culture on corporate strategy. The results obtained with this study of organizational culture significantly influence on corporate strategy. The only previous research results that are different from the results of this research is research conducted by Mavondo and Farell (2003), where research results indicate that organizational culture does not directly influence the performance but through the intervening variable of marketing orientation.

The effect of Organizational Learning towards Competitive Strategy and Company Performance: SEM analysis results of variables influence organizational learning (X2) on competitive strategy (Y1) is obtained directly influence the path coefficients and p-value 0251 and 0024 . Since the value p-value $<5 \%$, it says significantly. Given the path coefficient is positive (0251), this means that relations between the two variables is positive, meaning that the better learning organization, the better the competitive strategy. Such research has been done by Fang and Wang (2006), results of Fang and Wang's empirical research based on statistical calculations indicate that organizational learning affects the company's strategy. The four elements of corporate strategy, namely: cost, quality, flexibility, and reliability, while organizational learning indicators are: (i) personal mastery (personal excellence), (2) mental models, (3) shared vision, (4) team learning, and (5) systems thinking. Research conducted by McGuinness and Morgan (2005) which aims to find new construction, changes to organizational capabilities that determine organizational effectiveness in the implementation of marketing strategies. This study identifies the capabilities of organizational change as new construction that integrates the different steps in the lead and manage organizational change. Framework presents the new construction associated with market orientation and learning organizational strategies in the success of dynamic output. Conceptual discoveries in the study found a new definition, different constructions which can develop as a measurement of operational and organizational capabilities of the implementation of effective marketing strategies. The results can be concluded that market orientation and organizational learning have a positive relationship to changes in organizational capability and competitive strategy and to improve organizational performance. Organizational learning (X2) on the performance of the company (Y2) is obtained directly influence the path coefficients and p-value 00870343. Since the value $p$-value $>5 \%$, it is said insignificant. Another research done by Hardley and Mavondo, (2000) investigated the relationship between organizational learning, market orientation and organizational performance. On one hand, results suggest that organizational learning has a positive and significant impact on the marketing orientation. On the other hand, learning orientation influenced indirectly (mediating) on organizational performance. Other researchers which has different results from this research is research that conducted by Mavondo, Chimhanziand and Stewart (2005), they used a model of linkages between variables and an empirical test to assess the direct, indirect and total effects of the Learning Orientation (LO) and Market Orientation (MO) on the performance through the implementation of human resources and innovation (innovative administration, processes and products) as a mediator. This study also examined the effects of each variable to distinguish the effects of indirect and mediating effects. The result is a positive influence to $\mathrm{LO}$ corporate performance.

The Effect of Competitive Strategy towards Company Performance: Based on the result from SEM, the direct effect path coefficient from the effect of competitive strategy (Y1) toward company performance (Y2) is 0.199 and p-value is 0.030 . According from the result above, $p$-value is lesser than $5 \%$ therefore, it is said that significant. Because of the path coefficient is positive $(0.199)$ it means that both the variables have positive relationship, in other words, the better competitive strategy is, the higher company performance will be. According to Barth (2003), his research is in line with this research, that the competitive strategy have 
a significant effect on performance. Other researchers are in line with this research is Dimara et al (2004), results showed that all companies with low-cost strategy, market differentiation and focus strategy can improve profitability, but there was no significant difference for those who implement ISO 1989 -1993 with those applying in 1996-1999.

Research Limitation: In this research, the researcher generated the conceptual framework based from most previous published journals and the journals conducted their researches within big companies not the small ones. Hence, this is one of the limitations. Another limitation is the questionnaires were adopted based from previous journals' questionnaires that made some questions in this research's questionnaires were not appropriate in the researched field.

\section{Conclusion}

- The organizational culture affects insignificant towards competitive strategy. It means that organizational culture is not the only requirements to create competitive strategy. Nevertheless, organizational culture has effect significantly and indirectly towards the firms' strategy(s) through organizational learning.

- Organizational learning has significant positive relationship towards firm competitive strategy. Organizational learning also has insignificant correlation positively towards company performance but it has indirectly effect and significant towards company performance.

- Competitive strategy affects significantly and positively towards company performance. The better competitive strategy is the higher company performance will be.

\section{Recommendations}

For Practitioners: In this research, organizational learning has insignificant effect to the company performance and the variable is perceived in medium level from the researched respondents. Thus, the owners of the companies should focus and pay more attention on the organizational learning so as to increase their employees' competencies.

For Government: Organizational learning does not affect significantly towards company performance. This finding within this research shows that organizational learning in east Java SMEs is very low level of its application. Therefore, the support from the government is needed for those SMEs so as to increase the Budget Statistics of Region (APBD) particularly in east Java.

\section{References}

Aksu, A. A. \& Ozdemir, B. (2005). Individual Learning and Organization Culture in Learning Organization: Five-Star Hotels in Antalya Region of Turkey. Managerial Auditing Journal, 20(4), 422-441.

Alen, R. S., Merlyn, M. H., Margaret, B. T., Charles, S. W. \& Cynthia, W. (2006). A Comparison of Competitive Strategies in Japan and United State. S.A.M. Advanced Management Journal, 7(1), 1.

Allen, R. S. \& Helms, M. (2006). Linking Strategic Practices and Organizational Performance to Porter's Generic Strategies. Business Process Management Journal, 12(4), 433-454.

Argris, C. \& Schon, D. A. (1978). Organization Learning: A Theory of Action Perspective. Harlow: AddisonWesley.

Armstrong, A. \& Foley, P. (2003). Foundations for a learning organization: organization learning.

Barth, H. (2003). Fit among competitive strategy, administrative mechanism, and performance: a comparative study of small firms in mature and new industries.

Bate, P. (1984). The Impact of Organizational Culture on Approaches to Organizational Problem-solving. Organization Studies, 5, 43-66.

Batitci, U. S., Mendibil, K., Nudurupati, S., Garengo, P. \& Dan-Turner, T. (2006). Dynamic of Performance Measurement and Organizational Culture. International Journal of Operation and Production Management, 26(12), 1325-1350. 
Batitci, U. S., Mendibil, K., Nudurupati, S., Garengo, P. \& Dan-Turner, T. (2004). The Interplay between Performance Measurements. Organizational Culture and Management Styles Measuring Business Excellence, 8, 24-41.

Brown, A. \& Starkey, K. (1994).The Effect of Organizational Culture on Communication and Information. Journal of Management Studies, 31(6), 807-82.

Calantone, R. J., Cavusgil, S. T. \& Zhao, Y. (2002). Learning orientation, firm innovation capability, and firm performance. Industrial Marketing Management, 31(6), 515-524.

Caroll, M. G. \& Nafukho, F. M. (2006). Culture, Organizational Learning and Selected Employee Background Variables in Small-size Business Enterprises. Journal of European Industrial Training, 31(2), 127-144.

Chang, S. C. (2008). Organizational Learning, Environmental Uncertainty, and Firm's Performance. Journal of Korean Human Resource Management, 15(1), 153-172.

Chang, S. C. \&Lee, M. S. (2007). A Study on Relationship among Leadership, Organizational Culture, the Operation of Learning Organization and Employee, Job Satisfaction. The Learning Organization, 14 (2), 155-185.

Chatman, J. A. \& Jehn, K. A. (1994). Assessing the relationship between industry characteristics and organizational culture: How different can you be? Academy of Management Journal, 37, 522-553.

Chattel, A. (1995). Managing for the Future. London: Mc-Millan Press Ltd.

Damanpour, F., Szabat, K. A. \& Evan, W. M. (1989). The relationship between types of innovation and organizational performance. Journal of Management Studies, 26(6), 587-601.

Deal, T. E. \& Kennedy, A. A. (1982). Corporate Culture: The Rights and Rituals of Corporate Life. Reading, MA: Addison-Wesley

Denison, D. R. \& Mishra, A. K. (1995). Toward a Theory of Organizational Culture and Effectiveness. Organization Science, 6(2), 204-223.

Denison, D. R. (1990). Corporate Culture and Organizational Effectiveness, New York: John Wiley \& Sons.

Dewar, R. D. \& Dutton, J. E. (1986). The adoption of radical and incremental innovations: An empirical analysis. Management Science, 32(11), 1422-1433.

Dimara, E., Dimitris, S. \& Kostas, T. (2004). Strategic Orientation and Financial Performance of Firms Implementing ISO 9000. International Journal of Quality \& Reliability Management, 2(1), 72-89.

Dixon, N. (1994). The Organizational Learning Cycle: How We Can Learn Collectively. Maidenhead: McGrawHill.

Dodgson, M. (1973). Organizational Learning: A Review of Some Literatures. Organization Studies, 14, 375394.

Drucker, P. (1999). Management challenges for the 21st century. Harper Collins Publishers.

Edmondson, A. \& Moingeon, B. (1998). From Organizational Learning to the Learning Organization. Management Learning, 29(1), 5-20.

Ettlie, J. E. (1983). Organizational policy and innovation among suppliers to the food-processing sector. Academy of Management Journal, 26(1), 27-44.

Fang, S. C. \& Wang, J. F. (2006). Effects of Organizational Culture and Learning on Manufacturing Strategy Selection: An Empirical Study National Kaohsiung. International Journal of Management, 3(3).

Gardiner, P. \& Whiting, P. (1997). Success Factors in Learning Organization: An Empirical Study, Industrial and Commercial Training, 29(2), 41-48.

Garralt, B. (1990). Creating a Learning Organization: A Guide to Leadership, Learning and Development. Cambridge: Director Books.

Garratt, B. (1990). Creating a Learning Organization: A Guide to Leadership, Learning, and Development. New York: Simon \& Schuster.

Garvin, D. A. (1993). Building a learning organization. Harvard Business Review, 71, 78-91.

Hall, B. P. (2001). Values Development and Learning Organizations. Journal of Knowledge Management, 5(1), 19-32.

Hamel, G. \& Prahalad, C. K. (1994). Competing for the Future. Breakthrough Strategies, Boston, MA: Harvard Business School Press.

Hansson, B. (2006). Company-based determinants of training and the impact of training on company performance Results from an international HRM survey. Personnel Review, 36(2), 311-331 q Emerald Group Publishing Limited 0048-3486 DOI 10.1108/00483480710726163

Hardley, F. \& Mavondo, F. (2000). The relationship between learning orientation, market orientation. 
Hofstede, G. (1980). Culture's Consequences: International differences in work related values. Beverly Hill, CA, Sage.

Huber, G. P. (1991). Organizational Learning and the Contributing Processes and the Literatures. Organization Science, 2(1), 88-115.

Ibrahim, J. T. (2005). Strategic Pengembangan UKM di Jawa Timur. Badan Perencanaan Pembangunan Provinsi Jawa Timur.

Isaac, S. \& Michael, W. (1981). Handbook and Research Evaluation, $2^{\text {nd }}$ Ed. Sand Diego, EdITS Publisher.

Jones, G. R. (2000). Organizational theory (3rd Ed.). New York: Prentice-Hall

Kandemir, D. \& Hult, G. T. M. (2005). A conceptualization of an organizational learning culture in international joint ventures. Industrial Marketing Management, 34(5), 430-439.

Kasper, H. (2002). Culture and Leadership in Market-oriented Service Organizations. European Journal of Marketing, 36(9), 1047-1057.

Kelley, L. L., Deborah, A. B. \& Jeffrey, P. H. (2007). An exploration of the relationship between learning organizations and the retention of knowledge workers. The Learning Organization, 14(3), 204-221.

Khairuddin, M. (2002). The Moderating Affect of Distinctive Capabilities on the Competitive Strategy and Performance Relationships in Malaysian SMEs.

Kilman, R., Saxton, M. M. \& Serpa, R. (1985). Introduction: Five Key Issues in Understanding and Changing Culture, in Kilman, RH, MY Saxton, R Serpa, and associates (eds), Learning Control of the Corporate Culture, San Francisco: Jossey-Bass;

Kim, D. H. (1993). The Link between Individual and Organizational Learning. Sloan Management Review, 34(1), 37-50.

Koberg, C. S. \& Chusmir, L. H. (1987). Organization Culture Relationships with Creativity and Other Jobrelated Variables. Journal of Business Research, 15, 397-409.

Kusunoki, K., Nonaka, I. \& Nagata, A. (1998). Organizational capabilities in product development of Japanese firms: A conceptual framework and empirical findings. Organization Science, 9(6), 699-718.

Leithch, C., Harrison, R., Burgoyne, J. \& Blantern, C. (1996). Learning Organizations: The Measurement of Company Performance. Journal of European Industrial Training, 20(1), 31-44.

Liao, S. H., Fei, W. C. H. \& Liu, C. H. T. (2008). Relationship between Knowledge Inertia, Organizational Learning and Organization Innovation. Technovation, 28(4), 183-195.

Lock, P. \& Crawford, J. (1999). The Relationship between Commitment and Organizational Culture, Subculture, Leadership Style and Job Satisfaction in Organizational Change and Development. Leadership and Organizational Development Journal, 20, 365-373.

Lopez, S. P., Peon, J. M. \& Ordas, C. J. (2004). Managing knowledge: the link between culture and organizational learning. Journal of Knowledge Management, 8(6), 93-104.

Lund D. B. (2003). Organizational Culture and Job Satisfaction. Journal of Business \& Industrial Marketing, 18(3), 219-236.

Luthan, F. (2005). Organizational Behavior.10th Edition. The McGraw-Hill Companies Inc.

Martins, E. C. \& Terblanche, F. (2003). Building organizational culture that stimulates creativity and innovation. European Journal of Innovation Management, 6(1), 64-74.

Mavondo, F. \& Farrell, M. (2003). Cultural Orientation: It's Relationship with Market Orientation, Innovation and Organizational Performance. Management Decision, 41(3), 241-249.

Mavondo, F., Chimhanzi, J. \& Stewart, J. (2005). Learning Orientation and Market Orientation Relationship with Innovation, Human Resource Practices and Performance. European Journal of Marketing, 39(11/12), 1235-1263.

McGuinness, T. \& Morgan, R. E. (2005). The Effect of Market and Learning Orientation on Strategy Dynamics: The Contributing Effect of Organizational Change Capability. European Journal of Marketing, 39(11/12), 1306-1333. http://dx.doi.org/10.1108/03090560510623271mechanisms. The Learning Organization journal, 10(2), 74-82.

Merx-Chermin, M. \& Nijhof, W. J. (2005). Factors influencing knowledge creation and innovation in an organization. Journal of European Industrial Training, 29(2), 135-182.

Murray, P. \& Donegan, K. (2003). Empirical linkages between firm competencies and organizational learning. The Learning Organization, 10(1), 51-62.

Nazir, M. (1999). Metode Penelitian. Jakarta: Ghalia Indonesia. New York: Free Press.

Nonaka, I. \& Yamanouchi, T. (1989). Managing innovation as a self-renewing process. Journal of Business Venturing, 4(5), 299-315. 
Ogbonna, E. \& Lloyd, C. H. (2000). Leadership style, organizational culture and performance: empirical evidence from UK companies. Int. J. of Human Resource Management, 11(4), 766-788.

Örtenbland, A. (2004). The Learning Organization: Towards an Integrated Model. The Learning Organization, $11(2), 129-144$.

Peters, T. J. \& Waterman, R. H. (1982). In Search of Excellence: Lessons from America's Bestrun Companies, New York: Harper \& Row.

Pool, S. W. (2000). The Learning Organization: Motivating Employees by Integrating TQM Philosophy in a Supportive Organizational Culture. Leadership \& Organizational Development Journal, 21(8), 373378.

Popper, M. \& Lipshitz, R. (1995). Organizational Learning Mechanisms: A Structural Cultural Approach to Organizational Learning, Haifa: University of Haifa.

Porter, M. E. (1980). Competitive Strategy: Techniques for Analyzing Industries and Competitors.

Porter, M. E. (1998). Competitive Advantage: Creating and Sustaining Superior Performance, with a new introduction. New York: Free Press.

Prajogo, D. I. \& McDermott, C. M. (2005). The relationship between total quality management practices and organizational culture. International Journal of Operations and Production Management, 25(11), 1101-1122.

Robbins, S. P. (1990). Organizational theory: Structure, design, and application (3 Ed.). Englewood Cliffs, NJ: Prentice Hall.

Robbins, S. P. (2001). Organizational behavior (9th Ed.). Upper Saddle River, NJ: Prentice-Hall.

Santos-Vijande, M. L. \& Álvarez-G. L. I. (2007). Innovativeness and organizational innovation in total quality oriented firms: The moderating role of market turbulence. Technovation, 27(9), 514-532.

Sarros, J. C., Cooper, B. K. \& Santora, J. C. (2008). Building a climate for innovation through transformational leadership and organizational culture. Journal of Leadership \& Organizational Studies, 15(2), 145158.

Schein, E. H. (1990). Organizational Culture. American Psychologist, 45, 109-119.

Schein, E. H. (1992).Organizational Culture and Leadership, Jossey-Bass, San Francisco, CA.

Senge, P. M. (1990). The Fifth Discipline: The Art and Practice of the Learning Organization. New York: Douldeday.

Shrivastva, P. (1983). A Typology of Organizational Learning Systems. Journal of Management Studies, 20, 7-28.

Siew-Kim, J. L. \& Kelvin, Y. (2004). Corporate culture and organizational performance. Journal of Managerial Psychology, 19, 340-359.

Slater, S. F. \& Narver, J. C. (1995). Market orientation and the learning organization. Journal of Marketing, $59(3), 63-74$.

Small, A. \& Irvine, P. (2006). Towards a Framework for Organizational Learning. The Learning Organization, 13(3), 276-299.

Sugiyono, T. (2004). Metode Penelitian Bisnis. Bandung: CV Alfabeta, Indonesia.

Sunata, I. W. (2007). Pengaruh Sumberdaya Perusahaan Terhadap Kapabilitas, Keunggulan Kompetitif, Strategi Kompetitifdan Kinerja Perusahaan. Desertasi S3. Universitas Brawijaya Malang.

Sweeney, M. T. (1991). Benchmarking for Strategies Manufacturing Management. International Journal of Operations and Production Management, 14(9), 4-15.

Thompson, L. (2003). Improving the creativity of organizational work groups. Academy of Management Executive, 17(1), 96-109.

Tushman, M. \& Nadler, D. (1986).Organizing for innovation. California Management Review, 28(3), 74-92.

Uttal, B. (1983). The Corporate Culture Vultures. Fortune, 108(8), 66.

Valerie, D. \& Werner, B. (2006). Strategic alignment and middle level managers' motivation in a balanced scorecard setting. International Journal of Operations \& Production Management, 26(4), 429-448.

Wahyudi, D. (2008). Pengaruh Orientasi Pasarterhadap Orientasi Pembelajaran, Budaya Organisasi, Kepemimpinan, Inovasi, Strategi Kompetitifdan Kinerja (Surveiterhadap Stasiun Radio FM swasta di Jawa Timur). Disertasi S3. Universitas Brawijaya Malang, Indonesia.

Wilkins, A. \& Ouchi, W. G. (1983). Efficient Cultures: Exploring the Relationship between Culture and Organizational Performance. Administrative Science Quarterly, 28, 468-481.

Zaltman, G., Duncan, R. \& Holbeck, J. (1973). Innovations and organizations. New York: Wiley.

Zehir, C., Zafer, A. \& Haluk, T. (2006). Identifying Organizational Capabilities as Predictors of Growth and Business Performance. The Business Review, Cambridge; summer, 5, 2. ABI/INFORM Global. 